\title{
Factors Affecting the Performance of Commercial Banks (A Case Study on Commercial Banks in Ethiopia): CAMEL Ratings
}

\author{
Mr. Bekana Dembel \\ Lecturer at Bonga University, Department of Accounting and Finance, Bonga University \\ Postal Code:5040, P. O. Box 334 Bonga, Ethiopia
}

\begin{abstract}
This study tried to assess factors affecting the efficiency and performance of Ethiopian commercial banks. Nine years audited financial data (i.e.2010-2018) was used to analyze the effect of explanatory variables on the explained variables using explanatory research design with quantitative research approach. Banks play a great role in the development of the countries. They act as financial intermediaries between the parties with lack of capital and parties with surplus capital. In order to perform their functions first their financial healthiness should be improved. In this study performance of the banks was measured by ROA and efficiency of the banks by efficiency ratio. On the other hand, factors that could be affect the performance of the banks were capital adequacy, assets quality, management capacity, earning quality, liquidity position, GDP and age of banks were used using different measurement mechanisms. Random effect GLS regression result indicated that management capability, assets quality and earning quality significantly affect the performance of the banks measured by ROA. On the hand, assets quality, earning quality, liquidity and age of the banks has significant effect on the efficiency of the banks. Capital adequacy, GDP and age of the banks have no impact on the ROA, and capital adequacy, management capacity and GDP do not have significant effect on the performance of the banks measured by efficiency ratio. According to the finding, management capability and earning quality have positive effect on the performance of the banks.
\end{abstract}

Keywords: CAMEL, ROA, Performance of the banks, Efficiency ratio and commercial banks

DOI: $10.7176 /$ RJFA/11-5-01

Publication date:March $31^{\text {st }} 2020$

\section{Introduction}

Financial institutions are play a great role in the country's endeavor to sustainability in all directions. They serve as intermediaries between the parties with surplus capital and the parties with capital deficiencies. By doing so, they play vital role in maintaining effectiveness and efficiency of financial system. According to Cristina et al., (2009) financial development contributes to growth in various ways. "For example, financial institutions are better suited than individuals to identify potentially successful projects because these institutions are big enough to pay large fixed costs of collecting information about individual projects and to analyze this information more efficiently". The crucial effect of financial institutions on the economic development is depend on the financial development that deals with improvement in quantity, quality, and efficiency of financial intermediary services. This implies the quality and quantity of services provided by financial institutions is depend on their development that contribute to the development of the nation. According to Muhammed \& Irfan, (2015), financial development is determined by growth domestic product, savings, advances to deposit ratio export and import.

Banks are the element of financial institutions that serve as financial intermediaries in the economy. It play indispensable role in deciding the direction of financial markets that sustain the success of economic development. This is especially very crucial in developing countries that are known by capital deficiencies that hinder capital investment. According to Tesfaye (2014), banks play a vital role in economic development through engaging themselves in an intermediary role which enhances investment and growth. This implies this institutions accept saving from economy, provide loan to the parties with insufficient capital that in turn influence economic activities. Banks are the most leveraged industry of any economy, so stability and soundness is an important parameter in the banking system. The main goal of banks in today's financial condition is to maintain stability and make sure that they are resistant to outer shocks while at the same time being sensible and sound from inside (Dakito, 2015).

The history of formal financial system in Ethiopia is attached to the establishment of Bank of Abyssinia just a century back. Bank of Abyssinia was established as the first bank in 1905 based on the agreement signed between the Ethiopian government and the National Bank of Egypt, which was owned by the British. The motive behind this research was because banks are considered as large financial institutions in the financial sectors which facilitate the proper utilization of financial resources of a country. According to Uyen (2011), the banking sector is increasingly growing and it has witnessed a huge flow of investment. In addition to simply being involved in the financial intermediation activities, banks are operating in a rapidly innovating industry that urges them to create more specialized financial services to better satisfy the changing needs of their customers. As a result, the banking 
sector need to be studied well in order to aid the country's endeavor to develop its nation. Therefore, this study is entitled as factors affecting the performance of Commercial Banks in Ethiopia in order to identify and analyze the determinant factors of banks performance using CAMEL, GPD and age of banks.

\section{Statement of the Problem}

Banks are financial institutions that operate by borrowing funds; usually by accepting deposits or by borrowing in the money markets. The accepted funds from different directions are used to provide loans and to purchase financial securities in the markets. The main role of bank is serving as financial intermediaries between surplus and deficient parties. According to Zawadi (2013), banking sector plays an important role in sustaining financial markets and has a significant impact on the success of the economy. This implies the economic sustainability of one nation depend up on capital self-sufficiency of its citizens. It is obvious that there are two categories of citizens in particular country. These are: parties with surplus capital and parties with capital deficiency but with investment idea. Therefore, banks are serve as intermediaries between these two parties.

In developing countries like Ethiopia banks play vital role in economic development. This is because there is large economic imbalance among citizens. It supports by promoting capital formation, investment in new enterprises, promoting trade and industry, developing agriculture, balancing the development among regions, influencing economic activities, implementing monetary policy and export and import. The banking sector is increasingly growing and it has witnessed a huge flow of investment. In addition to simply being involved in the financial intermediation activities, banks are operating in a rapidly innovating industry that urges them to create more specialized financial services to better satisfy the changing needs of their customers (Sehrish et al., 2014). The hasty growth with new technology of banking sector may result in bank failure that result economic failure. This indicates the failure of banks lead to deposit withdrawals and the bank have to sell assets to confront these withdrawals. The ensuing fire sales lead to declines in asset prices, reducing the value of banks' assets. This in turn erodes the equity base of the banks and leads to a solvency problem.

Various studies were done in different countries at different times on the financial performance analysis of banks using different mechanisms. Different authors like (Kesha, 2005; Kumbirai, 2010; Sehrish et al., 2011; Tobias \& Themba, 2011; Kolapo \& Ayeni, 2012;Zawadi, 2013; Mukdad, 2014; Parvesh \& Sanjeey, 2014; Tesfaye, 2014; Dakito, 2015; Yonas \& Hamdu, 2015 and Malihe, 2015) done research on this area by taking different study variables. All scholars tried indicates the relationship between financial performance of banks and determinant factors that have effect on their performance. Some of them use CAMEL Ratings to assess and evaluate the financial performance of the banks, but the study that included GDP and age of banks as determinant factors were rare. Therefore in this study factors affecting the performance of the banks was studied by including GDP and age of banks.

\section{Objective of the Study \\ General Objective}

The general objective of this study was to analyze factors affecting the efficiency and performance of commercial banks in Ethiopia.

\section{Specific Objectives}

In line with general objective, the specific objectives of the study were stated as follows:

1. To assess the effect of capital adequacy on the performance of commercial banks.

2. To evaluate the impact of Assets quality on the performance of commercial banks.

3. To analyze the effect management capability on the performance of commercial banks.

4. To appraise the impact earning quality on the performance of commercial banks.

5. To ascertain the liquidity position on the performance of commercial banks.

6. To assess the impact GDP on the performance of commercial banks

\section{Hypotheses of the Study}

The following hypotheses were developed based on the empirical and theoretical study to be tested:

1. Capital adequacy has no effect on the performance of commercial banks

2. There is no significant difference between assets quality and performance of commercial banks

3. Management capability has no effect on the performance of commercial banks

4. There is no significant difference between earning quality and performance of commercial banks

5. Liquidity position has no effect on the performance of commercial banks

6. GDP has no effect on the performance of commercial banks

7. Bank's age has no effect on the performance of commercial banks 


\section{Significance of the Study}

The foremost purpose of this study was to assess and analyze factors affecting the performance of commercial banks in Ethiopia using CAMEL Ratings. In order to take remedial action and to make fruitful decision the management bodies of banks need to have core information about their banks. The study could be relevant to the strategic designer, policy maker and decision maker by providing valuable information about the status of their respective banks. The final result of this study could be used to understand the nature of the relationship that exists between firm performance and factors affecting their operational performance. Moreover, the study would be used as a stepping stone to other researchers who are intended to study on this area. Finally, the government and other stakeholders may take a lesson from the empirical result of the study.

\section{Scope of the Study}

In order to achieve the stated objective the researcher delimited the study to commercial banks found in Ethiopia. In order to assess the performance of the firms, variables such as: Capital adequacy, assets quality, management capability, earning quality, GDP and age of banks were taken as independent variables and performance of the firm measured by ROA and Efficiency ratio were considered as dependent variables. On the other hand, financial performance of the banks can be determined by different factors from different directions. In addition, the research design that was applied for this study was explanatory type of research design together with descriptive statistics and the secondary data that was used were data for 9 years.

\section{Limitation of the Study}

The main objective of the study was to examine the factors that affect the performance of commercial banks. The financial performance indicators selected for the study were limited to ROE and Efficiency ratio. The internal factors that could have effect on performance were: capital adequacy, assets quality, management capability, earning quality, liquidity position and sensitivity to market risk. However, financial performance does not only measured by ROA and efficiency ratios, and the factors that can affect performance is not confined to the above variables. On the other hand, probability sampling method was not applied to select the sample from the population which reduces the sample bias. Therefore, all the above limitations make the study difficult to generalize neither to the African banks nor to the world commercial banks.

\section{Organization of the Paper}

The paper was organized into five chapters in which the details of the study were stated. Chapter one deals with the introduction part in which background of the study, statement of the problem, objective of the study, research hypotheses, significance of the study, limitation of the study and scope of the study were discussed. Chapter two introduced the review of literature in which both theoretical as well as empirical studies related to the paper was reviewed. Chapter three deals with the issue of research methodology in which research design, research approach, sample design, sampling technique, sources of data and collection methods and data analysis and presentation methods was described. Chapter four is discussed about data analysis and discussion in which the data that was collected from various sources with different data collection techniques was analyzed and was discussed. Finally, chapter five was deals with research summary, conclusion and suggestions in which the summary, the conclusion reached and recommendation suggested was discussed.

\section{Conceptual Framework}

The main objectives of this study was to examine factors that affect the performance of commercial banks in Ethiopia. Performance indicators variables were ROA and efficiency ratio and independent variables were capital adequacy, assets quality, management capability, earning quality, liquidity, GDP and age of banks. The following figure indicates cause and relationship between dependent and independent variables. 


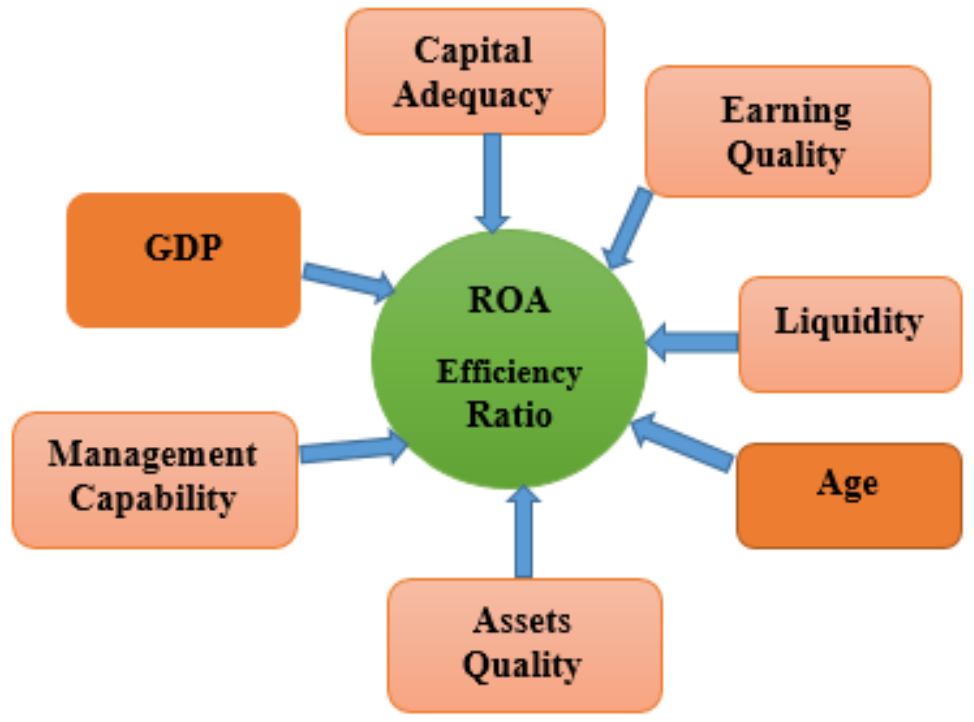

\section{Methods and Methodology \\ Research Design and Approach}

Research design is needed because it facilitates the smooth sailing of the various research operations, thereby making research as efficient as possible yielding maximal information with minimal expenditure of effort, time and money (Kothari, 2004). To achieve the research objective, explanatory research design was employed for the study. Explanatory research design helps to identify and evaluate the cause and effect relationship between the different variables under consideration. In addition, descriptive survey research design was also be used because the ranking was done to indicate the current status of the bank as it is. On the other hand, quantitative research approach was used because this approach used for testing objective theories by examining the relationship among variables

\section{Source of Data and Data Collection Methods}

Secondary data was used to conduct the research. The secondary source of data was collected from audited financial statements of selected commercial banks between the years (2010-2018). The required secondary data for the study was collected from National Bank of Ethiopia (NBE).

\section{Population of the Study and Sampling Design Population of the Study}

The main purpose of the study was to evaluate factors affecting the efficiency and performance of commercial banks in Ethiopia. Currently, there are 18 registered commercial banks in the country including government commercial bank. From this seven banks with audited financial statements between the years of 2010 to 2018 were taken.

\section{Sampling Design}

A sample design is a definite plan for obtaining a sample from a given population. It refers to the technique or the procedure the researcher would adopt in selecting items for the sample. Sample design may as well lay down the number of items to be included in the sample i.e., the size of the sample (Kothari, 2004). The sample was drawn from registered commercial banks in Ethiopia. For this study non-probability sampling was used because; even if banks are required to prepare yearly financial statements, banks with audited financial report for the stated years were selected. There are 18 commercial banks in Ethiopia.

\section{Variables of the Study and its measurement}

In this study, there are two categories of the study's variables. These are: dependent and independent variables. Independent variable is that variable which is antecedent to the dependent variables. The following table indicates different variables together with measurement. 
Table 1: Study Variable and their Maesurements

\begin{tabular}{|c|c|c|c|}
\hline \multicolumn{2}{|c|}{ Description of Variables } & Measurement of Variables & Indications \\
\hline \multicolumn{4}{|c|}{ Dependent Variables } \\
\hline \multicolumn{2}{|c|}{ Efficiency Ratio (ER) } & $\frac{\text { noninterest expenses }}{\text { net income }}$ & $\begin{array}{l}\text { Indicates that the bank is earning } \\
\text { more than it is spending. }\end{array}$ \\
\hline \multicolumn{2}{|c|}{ Return on Assets (ROA) } & Net income / Total assets & $\begin{array}{l}\text { It reflects the ability of a bank's } \\
\text { management to generate profits } \\
\text { from } \\
\text { the bank's assets }\end{array}$ \\
\hline \multicolumn{4}{|c|}{ Explanatory Variables } \\
\hline $\begin{array}{l}\text { Capital } \\
\text { Adequacy }\end{array}$ & TCTA & Total capital /Total asset & $\begin{array}{l}\text { The ratio reflects the ability of a } \\
\text { bank } \\
\text { withstand the unanticipated losses. }\end{array}$ \\
\hline Asset Quality & FATA & Fixed asset / Total assets & $\begin{array}{l}\text { It indicates how much fixed assets } \\
\text { are } \\
\text { hold by a company in comparison to } \\
\text { total assets }\end{array}$ \\
\hline $\begin{array}{l}\text { Management } \\
\text { capability }\end{array}$ & NIEGE & $\begin{array}{l}\text { Non-interest expense /Gross } \\
\text { expense }\end{array}$ & $\begin{array}{l}\text { It shows out of the gross expenses } \\
\text { how } \\
\text { much is the non-interest expense }\end{array}$ \\
\hline Earning Quality & NIITA & $\begin{array}{l}\text { Net interest income / Total } \\
\text { asset }\end{array}$ & $\begin{array}{l}\text { It shows how much net interest } \\
\text { income } \\
\text { generated for each birr total assets }\end{array}$ \\
\hline $\begin{array}{l}\text { Liquidity } \\
\text { Position }\end{array}$ & LATD & Liquid asset / Total deposit & $\begin{array}{l}\text { It shows the ability of a bank to meet } \\
\text { its } \\
\text { financial obligations }\end{array}$ \\
\hline Age of Banks & AgeB & Logarism of the age of banks & $\begin{array}{l}\text { The number of years the firm being } \\
\text { in existence or in operation since its } \\
\text { commencement }\end{array}$ \\
\hline GDP & $\begin{array}{l}\text { GDP at constant } \\
\text { market price }\end{array}$ & Log of GDP & \\
\hline
\end{tabular}

\section{Model Specification}

In this study, efficiency ratio and ROA were taken as dependent variables and CAMEL rations, GDP and age of banks were taken as independent variables. Therefore, the foremost purpose of this study is to analyze the factors that affect the efficiency and performance of commercial banks in Ethiopia. The financial performance of the firm is measured by efficiency ratio and ROA and the factors such as capital adequacy, assets quality, and management capability, earning quality, liquidity, GDP and age were assumed to be independent variables that have effect on the performance of commercial banks

$$
\begin{aligned}
& \mathrm{ERit}=\beta 0+\beta 1 \mathrm{a}(\mathrm{CA} i t)+\beta 1 \mathrm{~b}(\mathrm{AQ} i t)+\beta 1 \mathrm{c}(\mathrm{MCit})+\beta 1 \mathrm{~d}(\mathrm{EQ} i t)+\beta 1 \mathrm{e}(\mathrm{LP} i t) \\
& +\beta 1 \mathrm{f}(\operatorname{LogGDPit})+\beta 1 \mathrm{~g}(\text { AgeZit })+\mu i t \\
& \mathrm{ROA} i t=\beta 0+\beta 1 \mathrm{a}(\mathrm{CA} i t)+\beta 1 \mathrm{~b}(\mathrm{AQ} i t)+\beta 1 \mathrm{c}(\mathrm{MCit})+\beta 1 \mathrm{~d}(\mathrm{EQ} i t)+\beta 1 \mathrm{e}(\mathrm{LP} i t) \\
& +\beta 1 \mathrm{f}(\operatorname{LogGDP} i t)+\beta 1 \mathrm{~g}(\text { AgeZit })+\mu i t
\end{aligned}
$$

Where:

$$
\begin{array}{ll}
\text { ROA }=\text { Return on Assets } & \text { MC = Management Capability } \\
\text { ER }=\text { Efficiency Ratio } & \text { EQ }=\text { Earning Quality } \\
\text { CA }=\text { Capital Adequacy } & \text { LP = Liquidity Position } \\
\mathrm{AQ}=\text { Assets Quality } & \text { LogGDP }=\text { Log of GDP } \\
\mu=\text { Error Term } & \text { Age }=\text { Age of Banks }
\end{array}
$$

\section{Methods of Data Analysis}

Data analysis implies editing, coding classification and tabulation of collected data (Kothari, 2004). This implies data can be collected using various mechanisms and can be analyzed by using statistical procedures and the study employed both descriptive and inferential statistics. The first was descriptive data analysis that used to quantitatively describe the important features of the variables using mean, standard deviation, minimum and maximum. The second data analysis method was correlation analysis that is used to identify the relationship among variables using Pearson correlation analysis. However, correlation analysis shows only the degree of association 
among variables and does not permit the researcher to make causal inferences regarding the relationship between variables. Finally, multiple regressions were used to analyze the data that was collected. Moreover, data analysis was done by using STATA version 14.

\section{Results and Discussion}

Part I: Descriptive Analysis

In this study, the researcher was aimed to analyze the factors that affect efficiency and performance of Ethiopian commercial banks. To do so, financial ratios were taken to evaluate the performance of the banks and factors that affect the performance of the banks were discussed. The following table indicates descriptive analysis result.

Table 2: Descriptive Analysis

\begin{tabular}{|c|c|c|c|c|c|}
\hline Measurement & $\mathbf{N}$ & Minimum & Maximum & Mean & Std. Deviation \\
\hline ER & 63 & 40.90 & 5660.00 & 235.4810 & 69.24067 \\
\hline ROA & 63 & .40 & 178.60 & 5.9849 & 2.11019 \\
\hline $\mathrm{CA}$ & 63 & 4.00 & 19.21 & 11.6306 & 3.56196 \\
\hline $\mathrm{AQ}$ & 63 & .00 & 3.70 & 1.4214 & .82137 \\
\hline MQ & 63 & 2.00 & 7.00 & 5.1211 & 1.21159 \\
\hline $\mathrm{E}$ & 63 & 4.00 & 75.70 & 57.5122 & 10.78846 \\
\hline LP & 63 & 21.53 & 78.20 & 48.3329 & 5.30234 \\
\hline GDP & 63 & 379135.00 & 1834066.00 & 1109613.1111 & 500.48309 \\
\hline $\mathrm{AGE}$ & 63 & 15.00 & 55.00 & 25.1429 & 2.56064 \\
\hline Valid N (listwise) & 63 & & & & \\
\hline
\end{tabular}

\section{Source: author's survey data, 2020 STATA output}

The above table shows the overall descriptive statistics results of the performance of the banks. Accordingly, the mean value of Efficiency ratio is 235.48 with standard deviation of 69.2 . The mean value of ROA is 5.98 with 2.11 standard deviation.

Table 3: CAMEL Ratings

\begin{tabular}{|c|c|c|c|c|c|c|c|c|c|c|}
\hline \multirow{4}{*}{ Name of Banks } & \multicolumn{10}{|c|}{ CAMEL Rating } \\
\hline & \multirow{2}{*}{\multicolumn{2}{|c|}{$\begin{array}{c}\text { Cap. Adequacy } \\
\text { TCTA }\end{array}$}} & \multicolumn{2}{|c|}{ Assets Quality } & \multirow{2}{*}{\multicolumn{2}{|c|}{$\begin{array}{l}\text { Management } \\
\text { Capability } \\
\text { NIEGE }\end{array}$}} & \multirow{2}{*}{\multicolumn{2}{|c|}{$\begin{array}{c}\text { Earning Quality } \\
\text { NIITA }\end{array}$}} & \multirow{2}{*}{\multicolumn{2}{|c|}{$\begin{array}{l}\text { Liquidity } \\
\text { Position } \\
\text { LATD }\end{array}$}} \\
\hline & & & & $\mathrm{TA}$ & & & & & & \\
\hline & Mean & Rank & Mean & Rank & Mean & Rank & Mean & Rank & Mean & Rank \\
\hline $\begin{array}{l}\text { Commercial Bank } \\
\text { of Ethiopia }\end{array}$ & 6.33 & 7 & .63 & 7 & 3.58 & 7 & 55.34 & 5 & 46.10 & 4 \\
\hline NIB Bank & 15.93 & 1 & 1.20 & 4 & 5.91 & 1 & 53.81 & 6 & 51.11 & 3 \\
\hline United Bank & 11.84 & 4 & 1.11 & 6 & 5.61 & 4 & 58.18 & 3 & 52.83 & 2 \\
\hline Wegagan Bank & 15.90 & 2 & 1.62 & 2 & 5.62 & 3 & 51.82 & 7 & 56.11 & 1 \\
\hline Dashen Bank & 9.17 & 6 & 1.37 & 3 & 3.85 & 6 & 58.53 & 2 & 43.54 & 6 \\
\hline Abyssinia Bank & 10.89 & 5 & 1.19 & 5 & 5.90 & 2 & 68.25 & 1 & 43.05 & 7 \\
\hline Awash Inter. Bank & 11.95 & 3 & 2.81 & 1 & 5.37 & 5 & 56.63 & 4 & 45.58 & 5 \\
\hline
\end{tabular}

\section{Source: author's survey data, 2020 STATA output}

The second table indicates the CAMEL ratings of the banks based on the various financial ratios. Based on this, NIB international bank takes the first position using capital adequacy which is measured by total capital to total assets followed by Wegagan bank. Therefore, the result indicates these banks were found in a better position to withstand unanticipated losses. Commercial bank of Ethiopia was not found in a better condition regarding capital adequacy measured by total capital to total assets. In this study assets quality was taken to evaluate and to rank the banks. Fixed assets to total assets was taken to evaluate how much fixed assets are hold by a company in comparison to total assets. Awash international bank was found in the first place followed by Wegagan bank. This implies, those banks hold large amount of fixed assets relative to other banks.

Management capability deals with the Institute's ability to identify, respond and manage the financial risk involved in the day to day institutional operations like credit offers, transactions, interest rates etc. In this study, management quality was measured by the ratios of non-interest expense to gross expenses that indicates shows out of the gross expenses how much is the non-interest expense. NIB international bank is found on the first place with mean value of 5.90 followed by Abyssinia bank. The least is commercial bank of Ethiopia with 3.58. The elements of CAMEL is earning quality that measures the ability of the financial institutions to generate returns on the asset employed determine their profits. Net interest income to total assets is used to measure earning quality of the banks. In this regard Abyssinia bank found on the first rank followed by Dashen bank. Wegagan Bank found in the least position by this concern. The ranking activity was done by liquidity position of the firm that measures the ability of a bank to meet its financial obligations. Wegagan bank found in the best liquidity position during the study 
period.

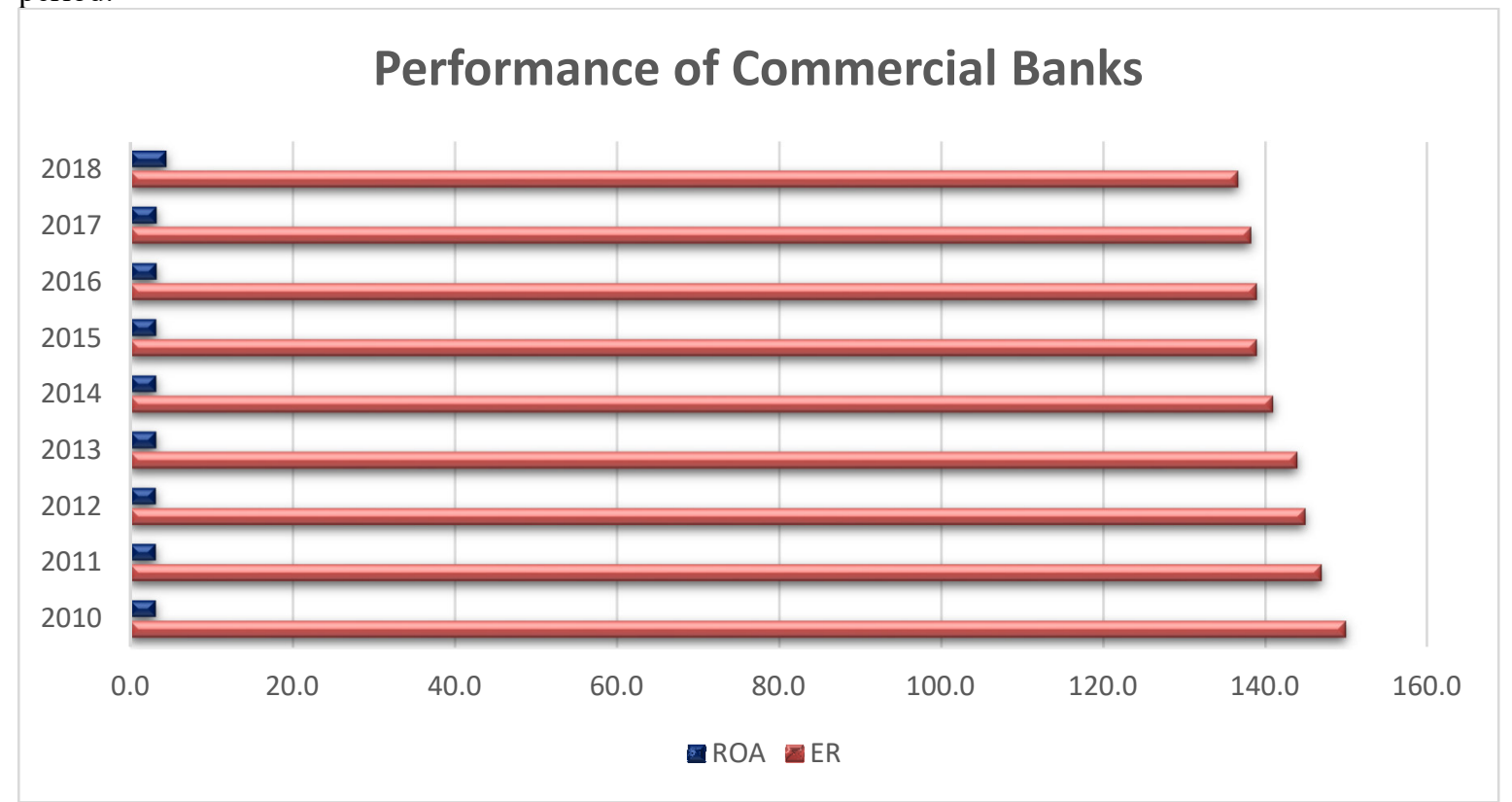

Figure1: Performance of Ethiopian Commercial Banks measured by ROA and ER

Correlation Result Analysis

Table 4: Correlation Analysis of ROA and independent variables

\begin{tabular}{|c|c|c|c|c|c|c|c|c|}
\hline & ROA & CA & AQ & $\mathrm{MC}$ & EQ & & Loggdp & LogAge \\
\hline ROA & 1.0000 & & & & & & & \\
\hline $\mathrm{CA}$ & $0.2525^{*}$ & 1.0000 & & & & & & \\
\hline AQ & -0.0067 & $0.3390 * *$ & 1.0000 & & & & & \\
\hline $\mathrm{MC}$ & 0.1589 & 0.5450 & 0.2049 & 1.0000 & & & & \\
\hline EQ & $+0.6457 * *$ & -0.2169 & 0.0155 & 0.2294 & 1.0000 & & & \\
\hline LQ & -0.1195 & 0.2040 & -0.1554 & -0.2876 & $-0.4242 * *$ & 1.0000 & & \\
\hline Loggdp & -0.1607 & 0.2033 & 0.0972 & 0.1818 & -0.2366 & -0.0590 & 1.0000 & \\
\hline LogAge & -0.0706 & $-0.4895 * *$ & -0.2440 & -0.3083 & -0.0595 & -0.0420 & 0.0000 & 1.0000 \\
\hline
\end{tabular}

* Correlation is significant at the 0.05 level (2-tailed).

** Correlation is significant at the 0.01 level (2-tailed).

Table 4 indicates that capital adequacy, management capability, and earning quality have positive relationship with financial performance measured by ROA. On the other hand, assets quality, liquidity age and GDP were negatively associated with performance measured by ROA. Accordingly, to improve the performance of the firm capital adequacy, management capability and earning quality have to be improved. 
Table 5: Correlation Analysis of ROA and independent variables

\begin{tabular}{|c|c|c|c|c|c|c|c|c|c|}
\hline & ER & CA & AQ & $\mathrm{MC}$ & $\quad \mathrm{EQ}$ & Q & \multicolumn{2}{|c|}{ Loggdp } & LogAge \\
\hline ER & 1.0000 & & & & & & & & \\
\hline $\mathrm{CA}$ & $0.2192 *$ & 1.0000 & & & & & & & \\
\hline AQ & -0.0209 & $0.3390 * *$ & * 1.0000 & & & & & & \\
\hline $\mathrm{MC}$ & 0.1147 & 0.5450 & 0.2049 & 1.0000 & & & & & \\
\hline EQ & $0.6738^{* *}$ & $-0.2169^{\prime}$ & * 0.0155 & 0.2294 & 1.0000 & & & & \\
\hline LQ & -0.1008 & $0.2040-$ & $-0.1554-$ & $-0.2876-$ & -0.4242 & 1.0000 & & & \\
\hline Loggdp & 0.1689 & $0.2033 \quad 0$ & 0.0972 & 0.1818 & $-0.2366-$ & $-0.0590 \quad 1$ & 1.0000 & & \\
\hline LogAge & -0.0272 & $-0.4895 * *$ & $=-0.2440$ & -0.3083 & -0.0595 & -0.0420 & 0.0000 & 1.0000 & \\
\hline
\end{tabular}

According to the above table, capital adequacy, management capability and earning quality have positive relationship with efficiency ratio that measures the earning power of the banks. On the other hand, assets quality, liquidity age and GDP negatively associated with efficiency ratio. Therefore, to earn more their spend the banks have to improve their capital adequacy, management capability and earning quality.

Part I: Regression Result of the Study

The main objective of this study is to appraise factors affecting efficiency and performance of Ethiopian commercial banks. As a result, two dependent variables and seven independent variables were discussed and dependent variables were expected to have impact on the performance of banks. The first econometrics analysis discussed about the effect of explanatory variables on the performance of commercial banks measured by ROA and the second analysis pointed out about Efficiency ratio and explanatory variables. Moreover, hypothesis was tested in order to choose the appropriate regression. Based on the regression result random-effects GLS regression was approved based on hausman test result.

Random-effects GLS regression $\quad$ Number of obs $=63$

Group variable: Banks

R-sq:

Within $=0.7377$

Between $=0.4720$

Overall $=0.6942$

Number of groups $=7$

Obs per group:

$\min =9$

$\operatorname{avg}=\quad 9.0$

$\max =9$

Wald chi2(7) $=124.87$

\begin{tabular}{|c|c|c|c|c|}
\hline $\operatorname{corr}\left(\mathrm{u} \_\mathrm{i}, \mathrm{X}\right)$ & $=0$ (assumed $)$ & $o b>c h i 2$ & 0.0000 & \\
\hline ROA & Coef. & Std. Err. & Z & $\mathrm{P}>|\mathrm{z}|$ \\
\hline $\mathrm{CA}$ & .4401306 & .7520772 & 0.59 & 0.558 \\
\hline $\mathrm{AQ}$ & -3.911856 & 2.222742 & -1.76 & $0.078 * *$ \\
\hline $\mathrm{MC}$ & 4.070463 & 2.01779 & 2.02 & $0.044 *$ \\
\hline EQ & 1.882721 & .1875844 & 10.04 & $0.000^{*}$ \\
\hline LQ & -.7167598 & .1351716 & -5.30 & $0.000 *$ \\
\hline Loggdp & -5.366228 & 3.4019 & -1.58 & 0.115 \\
\hline LogAge & -4.627299 & 5.066785 & -0.91 & 0.361 \\
\hline cons & 216.9779 & 54.2926 & 4.00 & 0.000 \\
\hline $\begin{array}{l}\text { sigma_u } \\
\text { sigma_e } \\
\text { rho }\end{array}$ & $\begin{array}{l}0 \\
11.406322 \\
0 \quad \text { (fraction of varia }\end{array}$ & e to $u$ i) & & \\
\hline
\end{tabular}

\section{Source: author's survey data, 2020 STATA output}

The regression result found in the above table shows that ROA explained by explanatory variables $69.42 \%$. As a result, assets quality, management capacity, earning quality and liquidity position significantly affect ROA at $5 \%$ and $10 \%$ level of significant. GDP, capital adequacy and age of banks were insignificant to have impact on 
ROA.

Random-effects GLS regression Group variable: Banks

$$
\begin{gathered}
\text { R-sq: } \\
\text { within }=0.7523 \\
\text { between }=0.4289 \\
\text { overall }=0.7023
\end{gathered}
$$

$\operatorname{corr}\left(\mathrm{u} \_\mathrm{i}, \mathrm{X}\right)=0$ (assumed)

Number of obs $=$
Number of groups $=$
$\begin{array}{cc}\text { Obs per group: } & \\ \text { min }= & 9 \\ \text { avg }= & 9.0 \\ \text { max }= & 9 \\ \text { Wald chi2(6) } & = \\ \text { Prob }>\text { chi2 } & =\end{array}$.

63

(Std. Err. adjusted for 7 clusters in Banks)

\begin{tabular}{|c|l|l|l|l|}
\hline ER & Coef. & $\begin{array}{c}\text { Robust } \\
\text { Std. Err. }\end{array}$ & $\mathrm{Z}$ & $\mathrm{P}>|\mathrm{z}|$ \\
\hline CA & 10.50165 & 22.69112 & 0.46 & 0.644 \\
\hline AQ & -119.8773 & 44.2965 & -2.71 & $0.007^{*}$ \\
\hline MC & 115.3368 & 115.9509 & 0.99 & 0.320 \\
\hline EQ & 60.42129 & 21.12918 & 2.86 & $0.004^{*}$ \\
\hline LQ & -22.07374 & 7.225875 & -3.05 & $0.002^{*}$ \\
\hline LogAge & -153.5054 & 142.2582 & -1.08 & 0.281 \\
\hline con & -93.59753 & 44.97282 & -2.08 & $0.037^{*}$ \\
\hline $\begin{array}{l}\text { sigma_u } \\
\text { sigma_e 348.56108 } \\
\text { rho 0 (fraction of variance due to u_i) }\end{array}$ & 2.46 & 0.014 \\
\hline
\end{tabular}

NB: $* 5 \%$

Source: author's survey data, 2020 STATA output

According to the above table, explanatory variables explained dependent variable (ER) $70.23 \%$. Accordingly, assets quality, earning quality, liquidity position and age of the banks were significantly affect the efficiency of the banks.

\section{Hypothesis Testing}

The objectives of this study was to evaluate the efficiency and performance of Ethiopian commercial banks. Two performance indicators i.e. ROA and Efficiency ratio (ER) were taken as dependent variables and CAMEL, GDP and age of banks were taken as independent variables. In the following section the formulated hypothesis were tested.

\section{$\mathrm{HO}_{1}$ : Capital adequacy has no effect on the performance of commercial banks}

According to the above regression result capital adequacy which is measured by total capital to total assets has no significant effect on the efficiency and performance of commercial banks. However, there positive relationship between capital adequacy and firm performance. As a result, null hypothesis have to be accepted.

\section{$\mathrm{HO}_{2}$ : There is no significant difference between assets quality and performance of commercial Banks}

The second hypothesis was formulated to indicate the relationship between assets quality and banks' performance. The regression result of the above shows that there is significant relationship between assets quality and performance of banks at 10\% level of significant. Fixed assets to total assets ratio was used to measure the effect of assets quality on performance of banks so that bank's performance is negatively affected by assets quality. This finding was not complement with what was obtained by Melaku (2017). Therefore, null hypothesis should be rejected.

\section{$\mathrm{HO}_{3}$ : Management capability has no effect on the performance of commercial banks}

In this study management quality was measured by non-interest expense to gross expense which indicates out of the gross expenses how much the non-interest expense. According to the above regression result, there is significant relationship between management capacity and banks performance measured by ROA at 5\% level significant. However, the effect of Management capacity is positive that is not consistence with the previous findings (Melaku, 2017). Therefore, null hypothesis is rejected. On the other hand, management capacity has no significant effect on the efficiency of commercial banks measured by efficiency ratio. As a result, null hypothesis have to be accepted.

\section{$\mathrm{HO}_{4}$ : There is no significant difference between earning quality and performance of commercial banks}

Earning quality which is measured by net interest income to total asset has negative and significant result on the both performance indicators. The negative and significant association of earning quality and performance of commercial bank is consistent with previous studies (Atlan et al., 2014 \& Melaku, 2017). Hence, null hypothesis need to be rejected. 
$\mathrm{HO}_{5:}$ Liquidity position has no effect on the performance of commercial banks

Both efficiency ratio and ROA were negatively and significantly affected by liquidity position of the banks which was measured by liquid assets to total deposit at 5\% level of significant. Previous findings of Melaku, 2017 and Mulualem, 2015 were not consistent with the finding. Therefore, the null hypothesis of the stated variable is rejected.

$\mathrm{HO}_{6:}$ GDP has no effect on the performance of commercial banks

According to the above random effect estimation GDP which was measured by logarithm of GDP has no effect on both performance indicators. Therefore, null hypothesis of the study about GDP and performance should be rejected.

$\mathrm{HO}_{7:}$ Bank's age has no effect on the performance of commercial banks

Random effect estimation of the above regression result indicates that there is negative and significant relationship between efficiency ratio and bank's age. As result, null hypothesis have to be rejected. On the other hand, there is no significant relationship between bank age and ROA.

\section{Conclusion and Recommendations Conclusion}

In this study, the researcher sought to examine factors affecting the financial performance of commercial banks in Ethiopia. Nine years audited financial data (i.e. between 2010 \& 2018) from seven banks were used to analyze to analyze the effect of explanatory variables on the performance of banks. Seven commercial banks with audited financial statement between study years were selected for study. Explanatory research design with quantitative research approach were used to analyze the bank performance. According to the regression result, management capability which was measured by the ratio of non-interest expense to gross expense and earning quality that was measured by the ratio of net interest income to total assets were positively and significantly affect the performance of the bank measured by ROA and efficiency ratio. On the other hand, assets quality and liquidity which were measured by fixed assets to total assets and liquid assets to total deposit respectively negatively and significantly affect the banks' performance between the study periods.

\section{Recommendations}

The main objectives of this study was to analyze the factors that affect the performance of Ethiopian commercial banks. Secondary data was collected from National bank of Ethiopia to be analyzed. Based on the findings of the study, the following recommendations were forwarded to the stakeholders:

$\stackrel{4}{4}$ According to the finding of the study management capability which was measured by Non-interest expense to gross expense positively affect the performance of banks. Therefore, the board of the banks must give due attention to the management quality to improve the performance of the banks.

$\Leftrightarrow$ Second, earning quality that measured by the ratio of net interest income to total assets do have positive and significant effect on the performance of commercial banks in Ethiopia in the study periods. This variable shows how much net interest income generated for each birr to total assets. As a result, the banks manager recommended to work on this variable to enhance the earning ability of their banks.

$\Rightarrow$ Descriptive statistics indicates that some of the banks under study achieved four and above four as per composite CAMEL ratings. Accordingly, National Bank of Ethiopia has to give due attention in controlling these banks because this rate indicates marginal performance and significantly below average.

$\Leftrightarrow$ Finally, Commercial bank of Ethiopia, Dashen bank and Abyssinia bank found in unsatisfactory performance and need immediate remedial action for the sake of securing their financial healthiness.

\section{References}

Altan, M., Beduk, A., \& Yusufazari, H.(2014). Performance Analysis of Banks in Turkey Using Camel Approach. 14th International Academic Conference, Malta.

Barr, Richard S. et al. (2002). "Evaluating the Productive Efficiency and Performance of U.S. Commercial Banks". Engineering Management, 28(8).

Cristina Arellano, Yan Bai Jing Zhang 2009 Firm Dynamics and Financial Development

Dakito Alemu 2015. Assessment of Banking Performance Using Capital Adequacy in Ethiopia Economics, 4(6), 106-111

Duttweiler, Rudolf (2009). "Managing Liquidity in Banks: A Top down Approach'. John Wiley and Sons

Frost, Stephen M., (2004). "Chapter 20 - Corporate Failures and Problem Loans". The Bank Analyst's Handbook: Money, Risk and Conjuring Tricks. John Wiley and Sons.

Ghulam A. \& Haroon H. (2010). Evidence on Structure Conduct Performance Hypothesis in Pakistani Commercial Banks. International Journal of Business and Management, 5(9), 174-187.

Grier, Waymond A. (2007). "Credit Analysis of Financial Institutions”. 2nd ed. Euro money Institution Investor PLC 
Hirtle, Beverly J. and Lopez, Jose A. (1999). “Supervisory Information and the Frequency of Bank Examination”. FRBNC Economic Review.

Keshar J. (2005). Health Check-up of Commercial Banks in the Framework of CAMEL: A Case Study of Joint Venture Banks in Nepal. The Journal of Nepalese Business Studies, 2(1), 41-55.

Kolapo T. \& Ayeni R. (2012). Credit Risk and Commercial Banks' Performance in Nigeria: A Panel Model Approach. Australian Journal of Business and Management Research, 2(2), 31-38.

Kothari, R. (2004). Research methodology. New Delhi, Indian: New age international Publishers.

Mabwe K. \& Robert W. (2010). A financial Ratio Analysis of Commercial Bank Performance in South Africa. African Review of Economics and Finance, 2(1), 30-53

Malihe R. (2015). Camels' Analysis in Banking Industry. Global Journal of Engineering Science and Research Management, 2(11), 11-26.

Melaku A. \& Melaku A. (2017). Financial Performance Analysis of Private Commercial Banks of Ethiopia: Camel Ratings. International Journal of Scientific and Research Publications, 7(10), 367-394.

Muhammad S., Irfanullah K., Javed I., Qamar A., Najam A., \& Raqibaz K.(2015). The Role of Financial institutions and the Economic Growth: A Literature Review. European Journal of Business and Management, $7(1), 95-98$

Mukdad I. (2014). A Comparative Performance of Two Banks in United Arab Emirates. Research Journal of Finance and Accounting, 5(21), 24-29.

Mulualem, M. (2015). Analyzing Financial Performance of Commercial Banks in Ethiopia: CAMEL Approach. (Master thesis). Addis Abeba University.

Parvesh K. \& Sanjeev D. (2014). Financial performance assessment of banking sector in India: A case study of old private sector banks. The Business \& Management Review, 5(3), 196-211.

Sehrish Gu, Khalid Zaman and Faiza Irshad (2014). Factors Affecting Bank Profitability in Pakistan, The Romanian Economic Journal no. 39, 61-87.

Tesfaye B. (2014). The Determinants of Ethiopian Commercial Banks Performance, European Journal of Business and Management, 6(14), 52-62.

Tobias O. \& Themba M. (2011). Effects of Banking Sectoral Factors on the Profitability of Commercial Banks in Kenya. Economics and Finance Review, 1(5), 1-30.

Uniform Financial Institutions Rating System (1997). Statements of Policy. The United States: Federal Deposit Insurance Corporation (FDIC)

Uyen Dang (2011). The Camel Rating System In Banking Supervision:A Case Study

Yonas M. \& Hamdu K. (2015). Soundness of Ethiopian Banks. International Journal of Finance \& Banking Studies, $4(2), 29-37$.

Zawadi A. (2013). Comparative Analysis of Financial Performance of Commercial Banks in Tanzania. Research Journal of Finance and Accounting, 4(19), 133-143. 